\title{
Gentamicin Dosing and Monitoring Challenges in End-Stage Renal Disease
}

\author{
Florczykowski $B^{1}$ and Storer $A^{2 *}$
}

${ }^{1}$ LSU Health- Shreveport, 1725 Claiborne Ave, Shreveport, LA 71130, USA

${ }^{2}$ ULM College of Pharmacy, 1725 Claiborne Ave, Shreveport, LA 71130, USA

\begin{abstract}
The second leading cause of mortality in end-stage renal disease patients on intermittent hemodialysis is infection. Gentamicin is frequently used in this patient population to treat infections due to the convenience of dosing only on hemodialysis days. Dosing recommendations vary among the most commonly used drug information databases. Differences are found in recommendations for both dosing and monitoring. Conflicting information found in drug information databases and primary literature can cause confusion among clinicians regarding the best way to dose and monitor gentamicin in ESRD patients on hemodialysis. While current practice utilizes posthemodialysis gentamicin dosing, there is primary literature that introduces the concept of pre-dialysis dosing. Predialysis gentamicin dosing may result in favorable pharmacokinetic profile.
\end{abstract}

Keywords: End-stage renal disease; Hemodialysis; Gentamicin

\section{Introduction}

The second leading cause of mortality in end-stage renal disease (ESRD) patients on intermittent hemodialysis is infection, preceded only by cardiovascular causes. The presence of indwelling catheters and repeated exposure to foreign materials during hemodialysis increase the risk of infection. Gentamicin is frequently used to treat infections in ESRD patients because of the convenient dosing profile in this patient population. The prolonged half-life in patients with ESRD allows for less frequent dosing, yet adequate therapeutic serum levels for extended time intervals. This pharmacokinetic profile allows for administration of intravenous gentamicin on scheduled outpatient hemodialysis days negating the need for an inpatient admission to administer IV antibiotics.

\section{Dosing}

Although gentamicin treatment is common in ESRD patients, determining the correct dose can be a challenge. Commonly used drug information databases have conflicting dosing recommendations for patients on hemodialysis (Table 1). Of the dosing references evaluated, Lexi-Comp recommends the most aggressive dosing strategies, including a loading dose as well as a higher maintenance dose. Micromedex has multiple dosing recommendations. One mimics the recommendation from the package insert and the other is a $2 / 3$ reduction of the dose used for a patient with normal renal function. The most comprehensive set of recommendations is found in Facts and Comparisons. It provides three different dosing strategies which are a culmination of what is found in each of the other databases, but proposes a $1 / 2$ reduction as opposed to the $2 / 3$ suggested by Micromedex. Of note, the $2 / 3$ reduction in Micromedex and $1 / 2$ reduction in Facts and Comparisons reference different editions of the same book [1-3]. The Micromedex recommendation comes from a publication from 1994, whereas the Facts and Comparisons recommendation comes from a publication from 2007.

To further complicate gentamicin dosing, there is also conflicting data regarding which weight is used to determine the initial dose (Table 2). Some sources suggest using actual body weight while others suggest using ideal body weight. All of the references agree on using an estimated lean body weight formula to arrive at a dose for obese patients. However, only one database recommends using a dosing weight formula for underweight patients.

\section{Timing of Dose}

Since aminoglycosides are dialyzable, current practice is to infuse gentamicin doses at the completion of hemodialysis (Table 1). However, many hemodialysis units administer the infusion during the last 30 minutes of hemodialysis. With this practice, some of the gentamicin infused will be cleared during hemodialysis preventing the patient from achieving optimal peak levels and altering intended pharmacokinetics. Utilizing the higher end of the dosing range may be warranted in patients who receive gentamicin while still on the dialysis machine.

A novel method, pre-dialysis gentamicin dosing [4-18] has been described as being similar to once-daily dosing in patients with normal renal function [12]. This dosing strategy allows for higher gentamicin doses and serum concentrations. As with all aminoglycosides, higher drug concentrations lead to a greater rate and extent of bactericidal activity $[5,6]$. Because gentamicin clearance during dialysis approaches that of normal kidney function [8], a large portion of the predialysis dose gets cleared and patients are not exposed to increased serum levels for prolonged durations. Although these studies show promising results, the pharmacokinetic profiles were obtained from computer extrapolations of small patient populations and have not been established in current practice. Larger prospective studies may be necessary prior to routinely adopting this dosing strategy for hemodialysis patients [19].

\section{Monitoring}

It is widely accepted that serum levels should be monitored closely due to the narrow therapeutic window of gentamicin. However, serum monitoring suggestions differ among drug information databases (Table 3). Ideal peak levels range between $4-6 \mathrm{mcg} / \mathrm{mL}$ for a urinary

*Corresponding author: Amanda Storer, Pharm.D. 1725 Claiborne Ave Shreveport, LA 71130, Tel: 318-632-2007; Fax: 318-632-2009; E-mail: aranzi@Isuhsc.edu

Received January 31, 2013; Accepted June 27, 2013; Published June 29, 2013

Citation: Florczykowski B, Storer A (2013) Gentamicin Dosing and Monitoring Challenges in End-Stage Renal Disease. Adv Pharmacoepidem Drug Safety 2: 135. doi:10.4172/2167-1052.1000135

Copyright: (c) 2013 Florczykowski B, et al. This is an open-access article distributed under the terms of the Creative Commons Attribution License, which permits unrestricted use, distribution, and reproduction in any medium, provided the original author and source are credited. 
Citation: Florczykowski B, Storer A (2013) Gentamicin Dosing and Monitoring Challenges in End-Stage Renal Disease. Adv Pharmacoepidem Drug Safety 2: 135 . doi:10.4172/2167-1052.1000135

Page 2 of 3

\begin{tabular}{|c|c|c|c|c|}
\hline $\begin{array}{l}\text { Drug Information } \\
\text { Source }\end{array}$ & Timing of Dose & Drug removal during dialysis & $\begin{array}{l}\text { Loading } \\
\text { Dose }\end{array}$ & Maintenance Dose \\
\hline $\begin{array}{l}\text { Gentamicin Package } \\
\text { Insert }\end{array}$ & $\begin{array}{l}\text { At the end of each } \\
\text { dialysis period }\end{array}$ & $\begin{array}{l}\text { Depends on type of dialysis used. An } 8 \text { hour HD may } \\
\text { reduce serum concentrations by } \\
\text { approximately } 50 \%\end{array}$ & None & $\begin{array}{l}1-1.7 \mathrm{mg} / \mathrm{kg} \text { depending on the severity of the } \\
\text { infection }\end{array}$ \\
\hline Lexi-Comp & $\begin{array}{l}\text { At the end of each } \\
\text { dialysis session }\end{array}$ & $\begin{array}{l}\text { Approximately } 50 \% \text { dialyzable, variable, dependant on } \\
\text { filter, duration and type of IHD }\end{array}$ & $2-3 \mathrm{mg} / \mathrm{kg}$ & $1.5-2 \mathrm{mg} / \mathrm{kg}$ every $48-72 \mathrm{hrs}$. \\
\hline Micromedex 2.0 & $\begin{array}{l}\text { At the end of each } \\
\text { dialysis session }\end{array}$ & Not specified & None & $\begin{array}{l}1-1.7 \mathrm{mg} / \mathrm{kg} \text { depending on severity of infection } \\
\text {-OR- } \\
2 / 3 \text { of the normal dose }\end{array}$ \\
\hline Facts and Comparisons & $\begin{array}{l}\text { At the end of each } \\
\text { dialysis period }\end{array}$ & $\begin{array}{l}\text { Depends on several factors, including the } \\
\text { dialysis method used. An } 8 \text {-hour HD session may } \\
\text { reduce serum concentrations of gentamicin by } \\
\text { approximately } 50 \%\end{array}$ & None & $\begin{array}{l}1 \text { to } 1.7 \mathrm{mg} / \mathrm{kg} \\
\text {-OR- } \\
\text { dosage of } 50 \% \text { of the usual dosage with sub- } \\
\text { sequent doses adjusted according to serum } \\
\text { concentrations } \\
\text {-OR- } \\
1.5 \text { to } 2 \mathrm{mg} / \mathrm{kg} \mathrm{IV} \\
\text { every } 48 \text { to } 72 \\
\text { hours after HD. }\end{array}$ \\
\hline
\end{tabular}

Table 1: Dosing recommendations.

\begin{tabular}{|c|c|c|c|}
\hline Database & $\begin{array}{l}\text { Weight Used for } \\
\text { Dosing }\end{array}$ & $\begin{array}{l}\text { Weight Used for } \\
\text { Dosing in Obese }{ }^{1} \\
\text { Patients }\end{array}$ & $\begin{array}{l}\text { Weight Used for } \\
\text { Dosing in } \\
\text { Underweight Patients }\end{array}$ \\
\hline Package Insert & ABW & DWo & No recommendation \\
\hline Lexi-Comp & IBW & DWo & No recommendation \\
\hline Micromedex & ABW & DWo & DWu \\
\hline $\begin{array}{l}\text { Facts and } \\
\text { Comparisons }\end{array}$ & ABW & DWo & No recommendation \\
\hline
\end{tabular}

${ }^{1}$ Obese $=>20 \%$ of IBW

$\mathrm{ABW}=$ Actual Body Weight, IBW=Ideal Body Weight, $\mathrm{DWO}=$ dosing weight for obese patients, $\mathrm{DWu}=$ dosing weight for underweight patients $\mathrm{DWo}=\mathrm{IBW}+0.4(\mathrm{ABW}-\mathrm{IBW})$; $\mathrm{DWu}=1.13 \times \mathrm{ABW}$

Table 2: Weight based dosing

\begin{tabular}{|c|c|c|}
\hline Database & Target Peak (mcg/mL) & Target Trough (mcg/mL) \\
\hline Package Insert & $<12$ & $<2$ \\
\hline Lexi-Comp & $\begin{array}{l}\text { 4-6: Urinary Tract Infection } \\
\text { 6-8: Serious Infection } \\
\text { 8-10: Life Threatening Infection }\end{array}$ & $\begin{array}{l}\text { 0.5-1: Serious Infection } \\
\text { 1-2: Life Threatening Infection }\end{array}$ \\
\hline Micromedex & $4-12$ & $<2$ \\
\hline $\begin{array}{l}\text { Facts and } \\
\text { Comparisons }\end{array}$ & $<12$ & $<2$ \\
\hline
\end{tabular}

Table 3: Monitoring

\begin{tabular}{|l|l|}
\hline Database & Recommendations \\
\hline Package Insert & None \\
\hline Lexi-Comp & $\begin{array}{l}\text { Consider re-dosing for pre-HD levels }<3-5 \mathrm{mg} / \mathrm{L} \text { or } \\
\text { post-HD levels of }<2 \mathrm{mg} / \mathrm{L}\end{array}$ \\
\hline Micromedex & None \\
\hline Facts and Comparisons & $\begin{array}{l}\text { Re-dose when pre-HD plasma concentration is }<3-5 \\
\mathrm{mg} / \mathrm{L} \text { or when post-HD plasma concentration is }<2 \mathrm{mg} / \mathrm{L}\end{array}$ \\
\hline
\end{tabular}

Table 4: Re-dosing.

tract infections and 6-12 $\mathrm{mcg} / \mathrm{mL}$ for bacteremia. Ideal trough levels are $<2 \mathrm{mcg} / \mathrm{mL}$. Although nephrotoxicity due to high serum trough levels is of little concern in ESRD patients, the trough achieved should still be $<2 \mathrm{mcg} / \mathrm{mL}$ to avoid a prolonged supratherapeutic area under the curve (AUC). Achieving therapeutic peak and trough levels helps to maximize therapeutic effect and minimize neurotoxicity and ototoxicity $[13,20]$.

A peak level should be drawn 30 minutes after completing the gentamicin infusion to allow for drug distribution. Peaks drawn prior to drug distribution will result in falsely elevated serum levels. Patients should remain in the hemodialysis unit for 30 minutes after the gentamicin infusion finishes to obtain an accurate peak level. Although this creates an inconvenience for both patient and staff, it is necessary to correctly monitor peak gentamicin levels and maximize efficacy.

\begin{tabular}{|l|l|}
\hline Database & References Used \\
\hline Lexi-Comp & {$[10]$} \\
\hline Micromedex & 1. Package Insert \\
\hline Facts and Comparisons & 2. [1] \\
\hline & 1. Package Insert \\
& 2. [1] \\
\hline & $3 .[10]$ \\
\hline
\end{tabular}

Table 5: Database references.

A serum trough level should be drawn within 30 minutes of the next gentamicin dose. Because gentamicin is readily cleared by hemodialysis, patients will not reach true serum trough levels until dialysis is completed. Waiting for these results would be a significant time burden on hemodialysis units. For this reason, pre-dialysis levels are widely relied upon instead of true trough levels. Some drug information sources suggest re-dosing gentamicin when pre-dialysis levels fall within the range of 3-5 $\mathrm{mcg} / \mathrm{mL}$ (Table 4).

\section{Clearance}

The amount of gentamicin cleared during hemodialysis is highly variable and multifactorial. Longer durations of hemodialysis, "high flux" dialyzer membranes, and increased flow rates on dialysis will all result in greater gentamicin clearance. Most references agree that approximately $50 \%$ of gentamicin is removed during an 8 hour hemodialysis session (Table 1). Typical hemodialysis sessions are 4 hours. Therefore, less than $50 \%$ of the drug may be removed. In addition to hemodialysis clearance, patients with residual renal function will continue to clear gentamicin between dialysis sessions.

\section{Summary}

As discussed above, gentamicin drug information found within drug databases is inconsistent which leads to challenges with gentamicin therapy in ESRD patients on hemodialysis. The abundance of research and primary literature available for gentamicin use in ESRD patients contributes to variety in dosing recommendations. Each database uses different references to arrive at their recommendations (Table 5), none of which have been shown to be more effective than another. In summary, there are many recommendations by reliable drug information sources for dosing gentamicin in ESRD patients on hemodialysis. Regardless of the dosing strategy implemented, correctly monitoring serum levels is essential to achieving maximum efficacy. 
Citation: Florczykowski B, Storer A (2013) Gentamicin Dosing and Monitoring Challenges in End-Stage Renal Disease. Adv Pharmacoepidem Drug Safety 2: 135. doi:10.4172/2167-1052.1000135

\section{References}

1. Aronoff GR, Bennett WM, Berns JS (2007) Drug Prescribing in Renal Failure: Dosing Guidelines for Adults and Children. (5thedn), Philadelphia, PA: American College of Physicians.

2. Bauer LA (1982) Rebound gentamicin levels after hemodialysis. Ther Drug Monit 4: 99-101.

3. Bennett WM, Arnoff GF, Golper TA (1994) Drug Prescribing in Renal Failure, American College of Physicians, Philadelphia, PA.

4. Brater DC, Hall SD (2008) Disposition and Dose Requirements of Drugs in Renal Insufficiency. In: Alpern RJ, Hebert SC, Seldin and Giebisch's The Kidney. (4thedn), Elsevier Inc 2779-2783.

5. Craig WA (1998) Pharmacokinetic/pharmacodynamic parameters: rationale for antibacterial dosing of mice and men. Clin Infect Dis 26: 1-10.

6. Dager WE, King JH (2006) Aminoglycosides in intermittent hemodialysis: pharmacokinetics with individual dosing. Ann Pharmacother 40: 9-14.

7. Dang L, Duffull S (2006) Development of a semimechanistic model to describe the pharmacokinetics of gentamicin in patients receiving hemodialysis. J Clin Pharmacol 46: 662-673.

8. Gentamicin. Drug Facts and Comparisons. Facts \& Comparisons [database online]. St. Louis, MO: Wolters Kluwer Health, Inc; April 2012. Accessed June $15,2012$.

9. Gentamicin. In: DRUGDEX® System [Internet database]. Greenwood Village Colo: Thomson Reuters (Healthcare) Inc. Updated periodically.

10. Heintz BH, Matzke GR, Dager WE (2009) Antimicrobial dosing concepts and recommendations for critically ill adult patients receiving continuous rena replacement therapy or intermittent hemodialysis. Pharmacotherapy 29: 562 577
11. Halpren BA, Axline SG, Coplon NS, Brown DM (1976) Clearance of gentamicin during hemodialysis: comparison of four artificial kidneys. J Infect Dis 133: 627 636 .

12. Lexi-Comp, Inc. (Lexi-DrugsTM ). Lexi-Comp, Inc., Hudson, Ohio: Lexi-Comp, Inc.; June 15, 2012.

13. Matsuo H, Hayashi J, Ono K, Andoh K, Andoh Y, et al. (1997) Administration of aminoglycosides to hemodialysis patients immediately before dialysis: a new dosing modality. Antimicrob Agents Chemother 41: 2597-2601.

14. Milutinovic J, Cutler RE, Hoover P, Meijsen B, Scribner BH (1975) Measurement of residual glomerular filtration rate in the patient receiving repetitive hemodialysis. Kidney Int 8: 185-190.

15. Moore RD, Lietman PS, Smith CR (1987) Clinical response to aminoglycoside therapy: importance of the ratio of peak concentration to minimal inhibitory concentration. J Infect Dis 155: 93-99.

16. Moore RD, Smith CR, Lietman PS (1984) The association of aminoglycoside plasma levels with mortality in patients with gram-negative bacteremia. J Infect Dis 149: 443-448.

17. Sowinski KM, Magner SJ, Lucksiri A, Scott MK, Hamburger RJ, et al. (2008) Influence of hemodialysis on gentamicin pharmacokinetics, removal during hemodialysis, and recommended dosing. Clin J Am Soc Nephrol 3: 355-361.

18. Teigen MM, Duffull S, Dang L, Johnson DW (2006) Dosing of gentamicin in patients with end-stage renal disease receiving hemodialysis. J Clin Pharmacol 46: $1259-1267$.

19. U S Renal Data System, USRDS 2011 Annual Data Report: Atlas of Chronic Kidney Disease and End-Stage Renal Disease in the United States, National Institutes of Health, National Institute of Diabetes and Digestive and Kidney Diseases, Bethesda, MD, 2011

20. Vercaigne LM, Ariano RE, Zacharias JM (2004) Bayesian pharmacokinetics of gentamicin in a haemodialysis population. Clin Pharmacokinet 43: 205-210. 